\title{
Own Grain Storage Structures: Is It Worth Investing?
}

\author{
Elisangela Domingues Vaz, Régio Marcio Toesca Gimenes, João Augusto Rossi Borges, \\ Rafael Todescato Cavalheiro, Andréia Maria Kremer \\ Federal University of Grande Dourados (UFGD), Brazil. \\ E-mail: rafaeltodescato@hotmail.com
}

Received: Oct. 27, 2019

Accepted: Nov. 21, 2019

Published: Nov. 26, 2019

doi:10.5296/jas.v8i2.15704

URL: https://doi.org/10.5296/jas.v8i2.15704

\begin{abstract}
Grain storage is strategic for agribusiness and therefore, it is important to consider the usefulness and benefits of its implementation. This study aims to identify the economic and financial viability of investing in grain storage structure at farm level using capital budgeting techniques. Considering the particularities of farms in the Midwest region of Brazil, the following investment valuation techniques were used: Net Present Value (NPV), Equivalent Uniform Annual Worth (EUAW), Internal Rate of Return (IRR), Modified Internal Rate of Return (MIRR), Discounted Payback (DP), Profitability Index (PI), Benefit/ Cost Ratio (B/C), Sensitivity Analysis and Monte Carlo simulation. The results of NPV and EUAW were positive. The results of IRR was $14.08 \%$ and MIRR was $11.39 \%$, with a payback of 11.81 years, an PI of US\$ 1.31 and a $\mathrm{B} / \mathrm{C}$ ratio of 3.16. From the risk analysis, it can be inferred that the investment is low risk since there is a $99.97 \%$ probability of NPV being greater than zero. Therefore, grain storage is a potentially viable alternative for increasing the competitiveness and wealth of Brazilian farmers, even in the context of an emerging economy.
\end{abstract}

Keywords: grain storage, economic viability, investment projects, investment decisions

\section{Introduction}

The United Nations (UN) estimates that the global population will be 9.8 billion by 2050 . In addition, a greater concentration of people in cities and an increase in per capita income will increase the demand for food by $70 \%$ (Bojanic, 2017). In this scenario, the optimistic expectation of agricultural production and productivity expansion (Saath and Fachinello, 2018), in contrast to the significant waste in post-harvest operations in developing countries (Kumar and Kalita, 2017), indicates the need to improve and expand the static capacity of grain warehouses, especially in Brazil (Patino et al., 2013), which has high rates of growth and acceleration for soybean production (Maranhão et al., 2019; Garrett and Rausch, 2016).

Brazilian agricultural products are potentially competitive in the foreign market, placing 
Brazilian agribusiness in a prominent position (Martinelli et al., 2010; Oliveira and Silveira, 2013). In 2018, Brazil reached a new record of agricultural exports, boosted by the second largest grain harvest in the history of Brazilian agriculture (CEPEA, 2019). Therefore, Brazil is one of the most important players in the world regarding food production.

In the 2017/18 harvest, Brazil produced 230 million tons of grain and had a static capacity deficit of 61 million tons (CONAB, 2018). The Food and Agriculture Organization of the United Nations (FAO, 2011) recommends that a country's static storage capacity be equal to $20 \%$ more than its annual agricultural production. However, there is a percentage of the Brazilian static capacity that does not meet the minimum requirements for good storage, which makes this deficit even larger, reaching 106 million tons.

Poor storage infrastructure creates vulnerability for rural businesses: farmers go to the market and sell grain during the harvest period, usually when prices are at their lowest levels (Maia et al., 2013; Oliveira et al., 2016). Therefore, grain storage becomes strategic for the agricultural business (Frederico, 2011; Patino et al., 2013), and it is important to consider the usefulness and benefits of its implementation (Poynder, 1999). Increased static capacity at farm level enables trading in off-season periods, minimizes production losses in quantity and quality, saves transportation, preserves grain quality, adapts consumption requirements and meets export standards set by the international commodity market (Cristiano et al., 2006; Puzzi, 2000).

However, investing in the storage structure is a complex decision and involves numerous variables and risks, the results and performance of which are very difficult to determine (Bocca and Galves, 2016). It is necessary to apply investment techniques, commonly used in Finance Theory, to assess the economic viability of the project (Damodaran, 2010). The analysis of the economic and financial viability of such an investment project becomes essential to support the decision making of investors, financial agents and technicians (Argilés, 2001; Aubin et al., 2011; King et al., 2010). It is important to know any project returns, establish parameters for validation and promote good performance.

Is it economically viable for farmers to invest in grain storage facilities? This is the guiding question of this study, which aims to identify the economic and financial viability of investing in grain storage structure at farm level using capital budgeting techniques.

Due to the contemporary nature of the subject and the small number of studies available in the literature, it is expected that the results of this paper will contribute to increase investments in grain storage structure at farm level. It is noteworthy that investments of this size represent a strategic decision that involves uncertainties, complexity and conflicts between risk and return. Therefore, the results presented here can support stakeholders' decision-making and contribute to the development of agribusiness.

\section{Materials and Methods}

\subsection{Study Object}

The work was based on data from the city of Dourados, located in the south of Mato Grosso 


\section{Al Macrothink}

Journal of Agricultural Studies

ISSN 2166-0379

2020, Vol. 8, No. 2

do Sul state, Midwest region of Brazil. This choice is justified by the agricultural potential of Dourados, which has 300,379.09 hectares of planted area, divided into 720 properties that grow corn and 706 that grow soy, totaling a production of 1,191,706 tons of grain (IBGE, 2019). Dourados also has an estimated static storage capacity of $1,142,633$ tons (CONAB, 2018). Although there is a balance between production and static capacity in Dourados, traditional Eastern cultivation areas continue to expand to the Midwest region of Brazil (Fliehr et al., 2019).

The economic viability analysis of the storage investment will be made for a capacity of $210,00060 \mathrm{~kg}$ bags of corn or soybeans, with good flexibility and operational receiving, drying and storage facilities.

The value of the initial investment was based on a budget prepared by a storage structure manufacturer that has factories in the Brazilian states of Rio Grande do Sul and Mato do Grosso do Sul. The study assumed that $50 \%$ of the investment will be funded from the farmer's own resources and 50\% from third party resources, at a rate of $10 \%$ per year. The credit line used is that of the Midwest Constitutional Financing Fund (FCO-Rural).

\subsection{Economic and Financial Viability Techniques}

The study was carried out in four stages. Initially, calculations were made to find the estimated minimum attractiveness rate through asset pricing modeling, calibrated to emerging country-specific parameters. The second stage consisted in the elaboration of free cash flow for the farmer. In the third stage, investment valuation techniques were applied: NPV, IRR, EUAW, Discounted Payback, PI, MIRR, B/C Ratio. And finally, in the fourth stage, the sensitivity and risk analysis of the investment were performed.

\subsubsection{Minimum Attractiveness Rate (MAR)}

Capital Asset Pricing Model (CAPM) is the most widely used asset pricing model for investors (Blank et al., 2014; Graham and Harvey, 2001). For the Minimum Attractiveness Rate, the cost of equity of the producer $(\mathrm{Ke})$ was estimated through the Adjusted Hybrid CAPM- based model proposed by (Pereiro, 2001) as follows:

$$
K_{e}=R f_{g}+R_{e}+\beta C_{L G}\left[\beta_{G G}\left(R_{M G}-R f_{g}\right)\right]\left(1-R^{2}\right)
$$

Where:

$K e=$ cost of equity;

$R f_{g}=$ global risk-free rate;

$R_{e}=$ country risk; 
$\beta C_{L G}=$ country beta;

$\beta_{G G}=$ average unlevered beta of comparable companies in the global market;

$R_{M G}=$ global market return;

$R^{2}=$ coefficient of determination

The Adjusted Hybrid CAPM-based model adjusts the global market premium for the domestic market using a beta country, which is represented mathematically by the slope of the regression between a local market index and the global market index (Teixeira and Cunha, 2017). (Pereiro, 2001) argues that the model allows the use of global market data in a simplified manner, despite some instability between the local and global market betas.

The global risk-free rate $\left(R f_{g}\right)$ was used to estimate MAR, considering a risk-free return on investment. Therefore, we opted for the interest rate paid on securities issued by the United States Government Treasury (T-Bonds), with a maturity of 30 years from the issue date (U.S. Department of the Treasury, 2018). To estimate country risk $\left(R_{c}\right)$, we used Emerging Markets Bond Index - EMBI+ Brazil, measured by the US bank JP Morgan (2018). This indicator evaluates the Brazilian foreign debt securities. According to Teixeira and Cunha (2017, p. 6) "for every 100 points expressed by EMBI + Brazil a surcharge is paid, which acts as a risk premium of $1 \%$ on US securities."

The country's beta $\left(\beta C_{L G}\right)$ was obtained through regression between local and global market indexes. The BOVESPA monthly variation was used as the local market index to represent the volatility of the Brazilian stock market from 2005 to January 2018 (INVESTING, 2018). The MSCI ACWI (All World Index) was chosen to estimate the overall rate of return. Released by Morgan Stanley Capital International, this index measures the monthly stock market performance of 46 countries ( 23 developed and 23 emerging). The monthly variation of the MSCI ACWI was collected in the same period of the IBOVESPA index.

The unlevered beta of comparable companies in the global market $\left(\beta_{G G}\right)$ was obtained through the Farming/Agriculture sector unlevered beta (0.60), calculated by Damodaran (2019). The MSCI ACWI - All Country World Index was used as a proxy for the global market return $\left(R_{M G}\right)$, considering the average annual return from 2005 to 2018. The coefficient of determination $\left(R^{2}\right)$ was obtained from the regression between local market volatility (monthly variations of the IBOVESPA index) and country risk variation (monthly variations of the EMBI + Brazil index), from April 1994 to December 2018. 


\subsubsection{Cash Flow Elaboration}

Information and assumptions from Table 1 were used for the cash flow projection, which details the possibilities of gains and expenses with corn and soybean crops, as well as production and productivity. Monetary values were converted from the real currency to the US dollar, considering the average commercial dollar exchange rate of $\mathrm{R} \$ 3.7118$ in February 2019. No specific rural property was used. Technical coefficients for storage structures were collected based on the following parameters and indicators: 
Table 1. Assumptions for the Producer's Free Cash Flow

\begin{tabular}{|c|c|c|}
\hline Indicators & Unit & Data \\
\hline \multicolumn{3}{|l|}{ 1.Soybean } \\
\hline 1.1 Area & ha & 3.818 \\
\hline 1.2 Productivity & $\mathrm{bag} / \mathrm{ha}$ & 55 \\
\hline 1.3 Production & bag & 210.000 \\
\hline 1.4 Average grain moisture & $\%$ & 20 \\
\hline 1.5 Selling earnings & US\$/bag & 1.13 \\
\hline 1.6 Drying cost reduction & US\$/bag & 0.53 \\
\hline 1.7 Freight cost reduction & US\$/bag & 0.51 \\
\hline 1.8 Quality gains & US\$/bag & 0.19 \\
\hline 1.9 Gains on residues & US\$/bag & 0.10 \\
\hline \multicolumn{3}{|l|}{ 2. Corn } \\
\hline 2.1 Area & ha & 2.625 \\
\hline 2.2 Productivity & $\mathrm{bag} / \mathrm{ha}$ & 80 \\
\hline 2.3 Production & bag & 210.000 \\
\hline 2.4 Average grain moisture & $\%$ & 16 \\
\hline 2.5 Selling earnings & US\$/bag & 0.32 \\
\hline 2.6 Drying cost reduction & US\$/bag & 0.65 \\
\hline 2.7 Freight cost reduction & US\$bag & 0.56 \\
\hline 2.8 Quality gains & US\$/bag & 0.17 \\
\hline 2.9 Gains on residues & US\$/bag & 0.08 \\
\hline 3. Total production in bags & bag & 420.000 \\
\hline 4. Average distance from place of delivery (Trade) & $\mathrm{Km}$ & 100 \\
\hline 5. Percentage of production to be stored & $\%$ & 100 \\
\hline 6. Static storage required & $\mathrm{t}$ & 25.200 \\
\hline 7. Grain silo capacity & $\mathrm{t}$ & 25.200 \\
\hline 8. Processing capacity & $\mathrm{t} / \mathrm{h}$ & 40 \\
\hline 9. Bag storage capacity & bag & 420.000 \\
\hline 10. Lifetime & years & 25 \\
\hline 11. Residual value & $\%$ & 20 \\
\hline 12. Credit line & Program & FCO Rural \\
\hline 13. Percentage to be funded & $\%$ & $50 \%$ \\
\hline 14. Fixed investment amount & US\$ & $2,675,745.73$ \\
\hline 15. Financed amount & US\$ & $1,337,872.86$ \\
\hline 16. Financing interest rate & $\%$ p.a. & $10,00 \%$ \\
\hline 17. Cost of equity & $\%$ p.a. & $10,1913 \%$ \\
\hline 18. Inventories & Inventory & 2 \\
\hline 19. Funrural & $\%$ & 1,5 \\
\hline 20. Income tax & $\%$ & 27,5 \\
\hline
\end{tabular}

Source: Prepared by the authors based on information from suppliers, producers, cooperatives, 


\section{Macrothink}

Mato Grosso Institute of Agricultural Economics (IMEA, 2019), Mato Grosso Soybean and Corn Producers Association (APROSOJA, 2019), Bank of Brazil (2019), Weber (2005), Cristiano et al. (2006), Gottardo and Cestari Júnior (2008), Paz and Aragão (2016) and Silva et al. (2006).

\subsubsection{Capital Investment Appraisal Techniques}

Before a project is implemented, the possibility of success or failure must be investigated. Possible returns from an investment project are verified by applying economic and financial viability techniques (Bordeaux-Rêgo et al., 2014). The techniques adopted in this study are presented in Chart 1.

Chart 1. Capital Investment Appraisal Techniques

\begin{tabular}{|c|c|c|}
\hline Technique & Equation & $\begin{array}{c}\text { Concept and } \\
\text { Impact on Decision }\end{array}$ \\
\hline $\begin{array}{c}\text { Discounted } \\
\text { payback }\end{array}$ & $\begin{array}{l}\text { Payback = minimum }\{\mathrm{i}\} \sum_{k=1}^{j} \frac{C F_{k}}{(1+M A R) k} \geq C F_{0} \\
\text { Where: } \\
\mathrm{CFk}=\text { Project cash flow at time } \mathrm{k} ; \\
\mathrm{MAR}=\text { Minimum Attractiveness Rate } \\
\mathrm{CF}_{0}=\text { Project cash flow at time zero. }\end{array}$ & $\begin{array}{l}\text { Discounted payback } \\
\text { uses the Minimum } \\
\text { Attractiveness Rate } \\
\text { to calculate the } \\
\text { present value of all } \\
\text { cash flows. In this } \\
\text { way, the time } \\
\text { required for the } \\
\text { return on invested } \\
\text { capital is more } \\
\text { accurately } \\
\text { determined. The } \\
\text { decision criterion is } \\
\text { based on the time } \\
\text { limit set by the } \\
\text { investor. When the } \\
\text { payback is below } \\
\text { this limit, the project } \\
\text { is accepted, when it } \\
\text { is above the limit, } \\
\text { the project is } \\
\text { rejected, indicating } \\
\text { high investment } \\
\text { risk. }\end{array}$ \\
\hline
\end{tabular}




\begin{tabular}{|c|c|c|}
\hline $\begin{array}{c}\text { Net present } \\
\text { value } \\
(\mathrm{NPV})\end{array}$ & $\begin{array}{l}N P V=\sum_{t=1}^{n} \frac{C F_{t}}{(1+M A R) t}-I_{0}+\sum_{t=1}^{n} \frac{I_{t}}{(1+M A R) t} \\
\text { Where: } \\
\text { CFt = cash flow (benefit) for each period; } \\
\text { MAR = Minimum Attractiveness Rate } \\
\text { Io = expected investment at time zero; } \\
\text { It = estimated investment value in each } \\
\text { subsequent period. }\end{array}$ & $\begin{array}{l}\text { NPV determines the } \\
\text { present value of } \\
\text { future cash flows, } \\
\text { discounted at the } \\
\text { Minimum } \\
\text { Attractiveness Rate. } \\
\text { When NPV is } \\
\text { greater than zero, } \\
\text { the project will } \\
\text { cover both the initial } \\
\text { investment and the } \\
\text { minimum } \\
\text { remuneration } \\
\text { required by the } \\
\text { producer, generating } \\
\text { cash surpluses. }\end{array}$ \\
\hline $\begin{array}{l}\text { Internal } \\
\text { Rate of } \\
\text { Return } \\
\text { (IRR) }\end{array}$ & $\begin{array}{l}I R R=I_{0}+\sum_{t=1}^{n} \frac{I_{t}}{(1+M A R) t}-I_{0}+\sum_{t=1}^{n} \frac{C F_{t}}{(1+M A} \\
\text { Where: } \\
\text { Io = investment amount at time zero (start of the } \\
\text { project); } \\
\text { It = expected amounts of investment at each } \\
\text { subsequent time; } \\
\text { MAR = Minimum Attractiveness Rate; } \\
\text { CF = expected cash inflows at each project stage } \\
\text { (cash benefits). }\end{array}$ & $\begin{array}{l}\text { The IRR represents } \\
\text { the periodic } \\
\text { equivalent rate of } \\
\text { return that is equal } \\
\text { to the project's } \\
\text { expected cash } \\
\text { inflows and } \\
\text { outflows at certain } \\
\text { time. As a decision } \\
\text { criterion, the project } \\
\text { is accepted when the } \\
\text { IRR is above the } \\
\text { Minimum } \\
\text { Attractiveness Rate } \\
\text { and rejected when it } \\
\text { is below. }\end{array}$ \\
\hline $\begin{array}{l}\text { Modified } \\
\text { Internal } \\
\text { Rate of } \\
\text { Return } \\
\text { (MIRR) }\end{array}$ & $\begin{array}{l}\text { MIRR }=\frac{\sum_{J=0}^{n}\left[\frac{Y_{j}}{(1+R R)^{n-j}}\right]}{\sum_{J=0}^{n}\left[\frac{C_{j}}{(1+M A R)^{j}}\right]}=(1+M I R R)^{n} \\
\text { Where: } \\
\mathrm{Yj}=\text { Positive cash flow in the period } \mathrm{j} ; \\
\mathrm{Cj}=\text { Negative cash flow in the period } \mathrm{j} ;\end{array}$ & $\begin{array}{l}\text { MIRR represents } \\
\text { the periodic } \\
\text { equivalent rate of } \\
\text { return that equals, at } \\
\text { any given time, the } \\
\text { project's expected } \\
\text { cash inflows and } \\
\text { outflows, } \\
\text { capitalizing positive }\end{array}$ \\
\hline
\end{tabular}




\begin{tabular}{|c|c|c|}
\hline & $\begin{array}{l}\text { RR = Reinvestment Rate; } \\
\text { MAR= Minimum Rate of Attractiveness. }\end{array}$ & $\begin{array}{l}\text { cash flows to the } \\
\text { end date by applying } \\
\text { a reinvestment rate, } \\
\text { while negative cash } \\
\text { flows are } \\
\text { decapitalized to the } \\
\text { zero-time date by } \\
\text { the application of } \\
\text { MAR. As a decision } \\
\text { criterion, the project } \\
\text { is accepted when } \\
\text { MIRR is above } \\
\text { MAR and rejected } \\
\text { when below. }\end{array}$ \\
\hline $\begin{array}{c}\text { Equivalent } \\
\text { Uniform } \\
\text { Annual } \\
\text { Worth } \\
\text { (EUAW) }\end{array}$ & $\begin{array}{l}E U A W=\sum_{t=1}^{n} \frac{C F_{t}}{(1+M A R) t} X \frac{\text { MAR } x(1+M A R)}{(1+M A R)^{t}-1} \\
\text { Where: } \\
\mathrm{CFt}=\text { project cash flow; } \\
\text { MAR = Minimum Attractiveness Rate; } \\
\mathrm{n}=\text { project lifetime. }\end{array}$ & $\begin{array}{l}\text { EUAW determines } \\
\text { a uniform annual } \\
\text { series representing } \\
\text { discounted cash } \\
\text { flow, which } \\
\text { considers MAR. } \\
\text { The highest positive } \\
\text { EUAW indicates the } \\
\text { best performing } \\
\text { scenario. }\end{array}$ \\
\hline $\begin{array}{l}\text { Profitabilit } \\
\text { y Index (PI) }\end{array}$ & $P I=\frac{\text { Present value of benefits }}{\text { Present value of cash disbursements }}$ & $\begin{array}{l}\text { PI assesses the cost } \\
\text { benefit of a project } \\
\text { by measuring the } \\
\text { value created by } \\
\text { each dollar invested. } \\
\text { PI is used as a } \\
\text { decision criterion: } \\
\text { when its value is } \\
\text { above one, the } \\
\text { project is accepted; } \\
\text { when below, it is } \\
\text { rejected. }\end{array}$ \\
\hline $\begin{array}{l}\text { Benefit/Cos } \\
\quad \mathrm{t}(\mathrm{B} / \mathrm{C})\end{array}$ & $B / C=\frac{V B(i)}{\operatorname{VC}(i)}$ & $\begin{array}{l}\text { The benefit/cost } \\
\text { ratio }(\mathrm{B} / \mathrm{C}) \text { is } \\
\text { obtained by dividing } \\
\text { the present value of }\end{array}$ \\
\hline
\end{tabular}




\section{Where:}

$\mathrm{B} / \mathrm{C}=$ Benefit $/$ Cost ratio;

VB (i) present value the rate $i$ - project discount rate, represented by the minimum return required (from the benefit sequence);

VC (i) present value at rate $i$ of project costs. benefits by the present value of project costs, applying the minimum attractiveness rate (MAR). In this sense, the project is accepted when the $\mathrm{B} / \mathrm{C}$ is above 1 . The higher the $\mathrm{B} / \mathrm{C}$, the higher the project profitability.

Source: Prepared by the authors based on (Assaf Neto, 2005; Brealey et al., 2013; Gitman, 2002; Longmore, 1989; Ross et al., 1998).

\subsubsection{Sensitivity Analysis}

Sensitivity analysis allows analyzing changes in the values obtained from investment valuation techniques. For example, NPV or IRR values may vary depending on changes in variables that directly affect cash flow estimates, such as selling price, quantity sold, and unit variable costs. Sensitivity analysis measures the extent to which a predetermined change in one or more input variables can influence the value of output variables (Acuña, 2015; Talavera et al., 2011). By analyzing sensitivity to endogenous and exogenous variables, the uncertainties and risks of a given project can be minimized (Casarotto Filho and Kopittke, 2010; Gitman, 2002). The NPV sensitivity analysis was chosen due to changes in Gross Operating Revenue, Fixed Investment, Operating Cost, Administrative Expense and Working Capital.

\subsubsection{Monte Carlo Simulation}

Monte Carlo simulation was used to analyze the risk involved in the investment analysis for the implementation of storage structures in the Brazilian Midwest. Monte Carlo simulation is a procedure that explicitly introduces the uncertainty of the input variables and transfers them to the modeling results (Martínez-Paz et al., 2014). The technique uses probability and random procedure functions and a value is generated for each variable. This procedure is replicated no less than a thousand times (Arnold and Yildiz, 2015; Vose, 2002), resulting in a series of values for NPV. It allows a distribution of indicators that can be used to study the variability and risk associated with investment valuation (Martínez-Paz et al., 2014).

In this study, the variables that presented the greatest effects on NPV in the sensitivity analysis were selected. A probability distribution for each variable was simulated 10,000 times in Excel. Triangular and normal forms of probability distribution are the most commonly used in Monte Carlo simulation. The triangular distribution is described by minimum, maximum and most likely values of the uncertain parameter, while the normal 
distribution is described by its mean and standard deviation (Lukuyu et al., 2019). Triangular distribution was used in this study. The repetition of the procedure generated a frequency distribution of the indicators, which made it possible to know the probability of success or failure of the investment project.

\section{Results and Discussion}

\subsection{Economic and Financial Viability Techniques}

The designed structure contains a road scale, four metal silos with aeration and thermometry system to control grain quality and temperature, a silo dryer with $18 \%$ moisture inlet and $13 \%$ outlet, drying temperature at 110 degrees, with capacity of $104 \mathrm{t} / \mathrm{h}$, a road forwarding silo with a capacity of $1,47060 \mathrm{~kg}$ bags. In addition to the silos, the structure has a cleaning and pre-cleaning machine, with input (2\%) and output (1\%) of impurity, capacity of $120 \mathrm{t} / \mathrm{h}$, five bucket elevators $(4.6 \mathrm{~m})$, seven chain conveyors and one oven. The project's fixed investment is detailed in Table 2.

Table 2. Identification of fixed investment

\begin{tabular}{l|l}
\multicolumn{1}{c|}{ Short Description } & \multicolumn{1}{c}{ Total value (US\$) } \\
\hline Civil works & $1,329,705.26$ \\
\hline Machines and equipment & $1,174,632.25$ \\
\hline Power grid & $139,078.88$ \\
\hline Road scale & $32,329.33$ \\
\hline Fixed Investment & $\mathbf{2 , 6 7 5 , 7 4 5 . 7 3}$ \\
\hline
\end{tabular}

Source: Prepared by the authors based on the budget of the silo manufacturer.

As shown, the budgeted investment totals US\$ 2,675,745.73 in expenditures on civil works, machinery and equipment, power grid and road balance. The budget shows that $55 \%$ of the investment is with civil works and electricity. The project estimates a static capacity of $210,00060 \mathrm{~kg}$ bags of corn and soybean. This means the property will have a capacity to store 420,000 bags of grain during the year.

\subsection{Determination of the Minimum Attractiveness Rate}

As described in section 2.2.1, we opted to use the Adjusted Hybrid CAPM-based model (AH-CAPM) to estimate the MAR. Firstly, all assumptions were defined for calculation. The global risk-free rate $\left(R f_{n}\right)$ was formed at a rate of $3.04 \%$ per annum according to the 30 -year

Treasury bond yield, obtained on January 29, 2019. The Country Risk $\left(R_{r}\right)$ used EMBI + 
Brazil at $2.45 \%$ per annum, also obtained on January 29,2019 . The country's beta $\left(\beta C_{\text {I. }}\right)$ was obtained by regression between the local stock market index (IBOVESPA) and the global market index (MSCI ACWI) for the period 2005-2018. The angular coefficient (slope) of this regression was 0.8756 . The unlevered beta of comparable companies in the global market

$\left(\beta_{\text {cre }}\right)$ was obtained by averaging the Farming/Agriculture unlevered beta, calculated at 0.60 by Aswath Damodaran for the period 2015-2019. The MSCI ACWI of 12.06\% annual average return was used as a proxy for the global market return $\left(R_{M G}\right)$. The amount was calculated from 2005 to 2018 . The coefficient of determination $\left(R^{2}\right)$ from the regression proposed in the AH-CAPM-based model was 0.0079 .

The Minimum Attractiveness Rate was obtained from the assumptions of the AH-CAPM-based model and the data presented above to support the decision making of the rural producer (Table 3).

Table 3. Producer capital cost calculation

\begin{tabular}{l|l}
\multicolumn{1}{c|}{ Description } & \multicolumn{1}{c}{ Total } \\
\hline Global Risk-Free Rate & $3,04 \%$ a.a. \\
\hline Country risk & $2,45 \%$ a.a. \\
\hline Country Beta & 0,8756 \\
\hline Unlevered Beta & 0,60 \\
\hline Global Market Return & $12,06 \%$ a.a. \\
\hline Determination coefficient & 0,0079 \\
\hline Producer Capital Cost $($ PCC) & $\mathbf{1 0 , 1 9 1 3 \%}$ a.a. \\
\hline
\end{tabular}

Source: Prepared by the authors.

The $10.19 \%$ MAR was considered in this study for economic and financial analysis of the investment. This value exceeds the cost of capital of third parties and represents the minimum remuneration required by the producer to decide on the viability of the investment.

The traditional CAPM model is widely used in developed and stable markets, however its use in emerging markets such as Brazil needs to be reviewed. Therefore, the AH-CAPM-based model proposed by Pereiro (2001) was used because it considers the risk and return 
specificities of emerging markets. When applied to the Brazilian reality, it resulted in an annual rate of $10.1913 \%$. The choice on this robust rate differs from the studies by Gottardo and Cestari Júnior (2008) and Paz and Aragão (2016) that used the cost of financing. It also differs from the studies by Vieira and Dalchiavon (2018) and Vorpagel et al. (2017) that adopted the Special System for Settlement and Custody (SELIC) rate. It is noteworthy that the use of the SELIC rate has received much criticism, given the constant variations of its historical series (Assaf Neto et al., 2008).

\subsection{Project Financing Plan}

The FCO-Rural financing line, proposed by the Brazilian Ministry of Regional Development, was the source of third party funds used to calculate the investment. This line of credit offers favorable conditions (interest rates, bankable limits, payment terms and grace periods) for farmers who wish to start, expand, modernize or relocate their ventures in the Midwest region of Brazil.

Under the FCO-Rural program, each operation has a maximum financing amount of US\$ 5,388,221.35, with an amortization period of 20 years, considering a 12-year grace period. For the contractor classified as a large rural producer, the interest rate corresponds to $10 \%$ per annum. Once the installment has been paid to maturity, in full or in part, a $15 \%$ discount on the installment interest is payable as a default bonus.

Before defining the amount of resources to be raised from third parties, a simulation was performed to determine the funding limit supported by the proposed investment project. From the results obtained it is suggested that the producer set his financing to a maximum of $90 \%$ of the total amount to be invested, as shown in Figure 1.

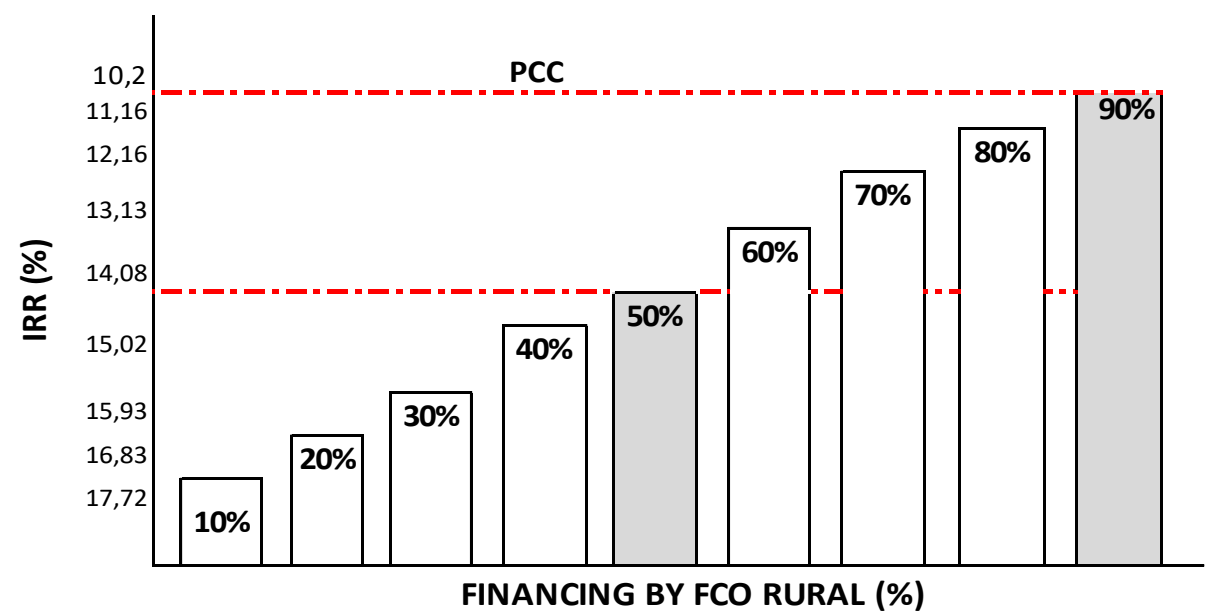

Figure 1. Determination of the funding limit supported by the investment

Caption: $\mathrm{PCC}=$ Producer Capital Cost

Source: Prepared by the authors.

In this study, it was decided to finance $50 \%$ of the project with its own resources and the other 50\% with FCO-Rural resources, that is, an amount of US\$1,337,872.86, at an interest 


\section{Macrothink Institute ${ }^{\mathrm{TM}}$}

rate of $10 \%$ per annum, which will be paid in 20 years, including a 12-year grace period. Over the 20 years, interest will be spent at US\$1,876,366.69, according to the amortization plan shown in Table 4.

Table 4. Financing Amortization Plan

\begin{tabular}{|c|c|c|c|c|c|}
\hline Year & $\begin{array}{c}\text { Principal } \\
\text { (US\$) }\end{array}$ & $\begin{array}{c}\text { Amortization } \\
\text { (US\$) }\end{array}$ & $\begin{array}{c}\text { Interest } \\
\text { (US\$) }\end{array}$ & $\begin{array}{c}\text { Installment } \\
\text { (US\$) }\end{array}$ & $\begin{array}{c}\text { Balance due } \\
\text { (US\$) }\end{array}$ \\
\hline 1 & $1,337,872.86$ & 0 & $113,719.19$ & $113,719.19$ & $1,337,872.86$ \\
\hline 2 & $1,337,872.86$ & 0 & $113,719.19$ & $113,719.19$ & $1,337,872.86$ \\
\hline 3 & $1,337,872.86$ & 0 & $113,719.19$ & $113,719.19$ & $1,337,872.86$ \\
\hline 4 & $1,337,872.86$ & 0 & $113,719.19$ & $113,719.19$ & $1,337,872.86$ \\
\hline 5 & $1,337,872.86$ & 0 & $113,719.19$ & $113,719.19$ & $1,337,872.86$ \\
\hline 6 & $1,337,872.86$ & 0 & $113,719.19$ & $113,719.19$ & $1,337,872.86$ \\
\hline 7 & $1,337,872.86$ & 0 & $113,719.19$ & $113,719.19$ & $1,337,872.86$ \\
\hline 8 & $1,337,872.86$ & 0 & $113,719.19$ & $113,719.19$ & $1,337,872.86$ \\
\hline 9 & $1,337,872.86$ & 0 & $113,719.19$ & $113,719.19$ & $1,337,872.86$ \\
\hline 10 & $1,337,872.86$ & 0 & $113,719.19$ & $113,719.19$ & $1,337,872.86$ \\
\hline 11 & $1,337,872.86$ & 0 & $113,719.19$ & $113,719.19$ & $1,337,872.86$ \\
\hline 12 & $1,337,872.86$ & 0 & $113,719.19$ & $113,719.19$ & $1,337,872.86$ \\
\hline 13 & $1,337,872.86$ & $167,234.11$ & $113,719.19$ & $280,953.30$ & $1,170,638.76$ \\
\hline 14 & $1,170,638.76$ & $167,234.11$ & $99,504.29$ & $266,738.40$ & $1,003,404.65$ \\
\hline 15 & $1,003,404.65$ & $167,234.11$ & $85,289.40$ & $252,523.50$ & $836,170.54$ \\
\hline 16 & $836,170.54$ & $167,234.11$ & $71,074.50$ & $238,308.60$ & $668,936.43$ \\
\hline 17 & $668,936.43$ & $167,234.11$ & $56,859.60$ & $224,093.70$ & $501,702.32$ \\
\hline 18 & $501,702.32$ & $167,234.11$ & $42,644.70$ & $209,878.81$ & $334,468.22$ \\
\hline 19 & $334,468.22$ & $167,234.11$ & $28,429.80$ & $195,663.91$ & $167,234.11$ \\
\hline 20 & $167,234.11$ & $167,234.11$ & $14,214.90$ & $181,449.01$ & 0 \\
\hline
\end{tabular}

Source: Prepared by the authors.

The financing modality adopted here uses the FCO-Rural credit line, which aims to serve the 


\section{Macrothink}

Journal of Agricultural Studies

ISSN 2166-0379 2020, Vol. 8, No. 2

agricultural and agro-industrial productive sector of the Midwest region. Given the difficulty in accessing credit in Brazil (Lopes et al., 2016), this choice positively differentiates this work from most Brazilian economic viability studies, which commonly use the Warehouse Construction and Expansion Program (PCA), a credit line of the National Bank for Economic and Social Development (BNDES) (Paz and Aragão, 2016; Vieira and Dalchiavon, 2018; Vorpagel et al., 2017).

\subsection{Producer's Free Cash Flow (PFCF)}

Based on the parameters detailed in Table 1, the free cash flow of the producer was prepared to estimate the working capital necessary to support the expenses of a storage structure until the revenue begins. The PFCF presented in Table 5 was calculated for a period of 25 years. 


\section{MInstitute Macrothink $_{\text {ins }}$}

Journal of Agricultural Studies

ISSN 2166-0379

2020, Vol. 8, No. 2

Table 5. Producer's Free Cash Flow

\begin{tabular}{|c|c|c|c|c|c|c|c|c|c|c|c|}
\hline Accounts & $\begin{array}{c}\text { Year } \\
0\end{array}$ & $\begin{array}{c}\text { Years } \\
1-12\end{array}$ & $\begin{array}{l}\text { Years } \\
13-14 \\
\end{array}$ & $\begin{array}{c}\text { Year } \\
15 \\
\end{array}$ & $\begin{array}{c}\text { Year } \\
16\end{array}$ & $\begin{array}{c}\text { Year } \\
17 \\
\end{array}$ & $\begin{array}{c}\text { Year } \\
18\end{array}$ & $\begin{array}{c}\text { Year } \\
19\end{array}$ & $\begin{array}{c}\text { Year } \\
20\end{array}$ & $\begin{array}{l}\text { Years } \\
21-24 \\
\end{array}$ & $\begin{array}{c}\text { Year } \\
25 \\
\end{array}$ \\
\hline $\begin{array}{c}\text { 1. Gross } \\
\text { Operating } \\
\text { Revenue }\end{array}$ & 0 & 907,484 & 907,484 & 907,484 & 907,484 & 907,484 & 907,484 & 907,484 & 907,484 & 907,484 & 907,484 \\
\hline 1.1 Soybean & 0 & 533,514 & 533,514 & 533,514 & 533,514 & 533,514 & 533,514 & 533,514 & 533,514 & 533,514 & 533,514 \\
\hline $\begin{array}{c}\text { 1.1.1 Selling } \\
\text { earnings }\end{array}$ & 0 & 236,489 & 236,489 & 236,489 & 236,489 & 236,489 & 236,489 & 236,489 & 236,489 & 236,489 & 236,489 \\
\hline $\begin{array}{l}\text { 1.1.2 Drying } \\
\text { cost reduction }\end{array}$ & 0 & 112,021 & 112,021 & 112,021 & 112,021 & 112,021 & 112,021 & 112,021 & 112,021 & 112,021 & 112,021 \\
\hline $\begin{array}{l}\text { 1.1.3 Freight } \\
\text { cost reduction }\end{array}$ & 0 & 107,495 & 107,495 & 107,495 & 107,495 & 107,495 & 107,495 & 107,495 & 107,495 & 107,495 & 107,495 \\
\hline $\begin{array}{c}\text { 1.1.4 Quality } \\
\text { gains }\end{array}$ & 0 & 56,576 & 56,576 & 56,576 & 56,576 & 56,576 & 56,576 & 56,576 & 56,576 & 56,576 & 56,576 \\
\hline $\begin{array}{l}\text { 1.1.5 Gains on } \\
\text { residues }\end{array}$ & 0 & 20,933 & 20,933 & 20,933 & 20,933 & 20,933 & 20,933 & 20,933 & 20,933 & 20,933 & 20,933 \\
\hline 1.2 Corn & 0 & 373,969 & 373,969 & 373,969 & 373,969 & 373,969 & 373,969 & 373,969 & 373,969 & 373,969 & 373,969 \\
\hline $\begin{array}{l}\text { 1.2.1 Selling } \\
\text { earnings }\end{array}$ & 0 & 67,325 & 67,325 & 67,325 & 67,325 & 67,325 & 67,325 & 67,325 & 67,325 & 67,325 & 67,325 \\
\hline $\begin{array}{l}1.2 .2 \text { Drying } \\
\text { cost reduction }\end{array}$ & 0 & 137,480 & 137,480 & 137,480 & 137,480 & 137,480 & 137,480 & 137,480 & 137,480 & 137,480 & 137,480 \\
\hline $\begin{array}{l}1.2 .3 \text { Freight } \\
\text { cost reduction }\end{array}$ & 0 & 117,678 & 117,678 & 117,678 & 117,678 & 117,678 & 117,678 & 117,678 & 117,678 & 117,678 & 117,678 \\
\hline $\begin{array}{c}\text { 1.2.4 Quality } \\
\text { gains }\end{array}$ & 0 & 35,643 & 35,643 & 35,643 & 35,643 & 35,643 & 35,643 & 35,643 & 35,643 & 35,643 & 35,643 \\
\hline $\begin{array}{l}1.2 .5 \text { Gains on } \\
\text { residues }\end{array}$ & 0 & 15,841 & 15,841 & 15,841 & 15,841 & 15,841 & 15,841 & 15,841 & 15,841 & 15,841 & 15,841 \\
\hline 2. Sales Taxes & 0 & 13,612 & 13,612 & 13,612 & 13,612 & 13,612 & 13,612 & 13,612 & 13,612 & 13,612 & 13,612 \\
\hline $\begin{array}{c}\text { 3. Net } \\
\text { Operating } \\
\text { Revenue }\end{array}$ & 0 & 893,871 & 893,871 & 893,871 & 893,871 & 893,871 & 893,871 & 893,871 & 893,871 & 893,871 & 893,871 \\
\hline $\begin{array}{c}\text { 4. Warehouse } \\
\text { Operating } \\
\text { Cost }\end{array}$ & 0 & 147,103 & 147,103 & 147,103 & 147,103 & 147,103 & 147,103 & 147,103 & 147,103 & 147,103 & 147,103 \\
\hline 5.Gross Profit & 0 & 746,768 & 746,768 & 746,768 & 746,768 & 746,768 & 746,768 & 746,768 & 746,768 & 746,768 & 746,768 \\
\hline $\begin{array}{l}\text { 6. Warehouse } \\
\text { Administrative } \\
\text { Cost } \\
\end{array}$ & 0 & 140,297 & 140,297 & 140,297 & 140,297 & 140,297 & 140,297 & 140,297 & 140,297 & 140,297 & 140,297 \\
\hline 7.EBTIDA (1) & 0 & 606,471 & 606,471 & 606,471 & 606,471 & 606,471 & 606,471 & 606,471 & 606,471 & 606,471 & 606,471 \\
\hline $\begin{array}{c}8 . \\
\text { Depreciation } \\
\end{array}$ & 0 & 107,029 & 107,029 & 107,029 & 107,029 & 107,029 & 107,029 & 107,029 & 107,029 & 107,029 & 107,029 \\
\hline 9.EBIT (2) & 0 & 499,441 & 499,441 & 499,441 & 499,441 & 499,441 & 499,441 & 499,441 & 499,441 & 499,441 & 499,441 \\
\hline $\begin{array}{c}\text { 10. Financing } \\
\text { payment }\end{array}$ & 0 & 113,719 & 280,953 & 252,523 & 238,308 & 224,093 & 209,878 & 195,663 & 181,449 & 0,00 & 0,00 \\
\hline 11.EBT (3) & 0 & 385,722 & 218,488 & 246,918 & 261,133 & 275,348 & 289,563 & 303,777 & 317,992 & 499,441 & 499,441 \\
\hline 12. Income tax & 0 & 49,911 & 49,911 & 49,911 & 49,911 & 49,911 & 49,911 & 49,911 & 49,911 & 49,911 & 49,911 \\
\hline $\begin{array}{c}13 . \text { Net } \\
\text { Operating } \\
\text { Income (NOI) }\end{array}$ & 0 & 335,811 & 168,576 & 197,006 & 211,221 & 225,436 & 239,651 & 253,866 & 268,081 & 449,530 & 449,530 \\
\hline $\begin{array}{c}14 . \\
\text { Depreciation }\end{array}$ & 0 & 107,029 & 107,029 & 107,029 & 107,029 & 107,029 & 107,029 & 107,029 & 107,029 & 107,029 & 107,029 \\
\hline $\begin{array}{c}\text { 15. Operating } \\
\text { Cash Flow } \\
(\mathrm{OCF})\end{array}$ & 0 & 442,840 & 275,606 & 304,036 & 318,251 & 332,466 & 346,681 & 360,896 & 375,111 & 556,560 & 556,560 \\
\hline $\begin{array}{c}16 . \text { Fixed } \\
\text { Investment }\end{array}$ & $2,675,745$ & 0 & 0 & 0 & 0 & 0 & 0 & 0 & 0 & 0 & 535,149 \\
\hline $\begin{array}{c}\text { 17. Working } \\
\text { capital }\end{array}$ & 287,400 & 0 & 0 & 0 & 0 & 0 & 0 & 0 & 0 & 0 & $287,400.26$ \\
\hline $\begin{array}{c}18 . \\
\text { Producer's } \\
\text { Cash Flow } \\
\text { (PFCF) } \\
\end{array}$ & $-2,963,145$ & 442,840 & 275,606 & 304,036 & 318,251 & 332,466 & 346,681 & 360,896 & 375,111 & 556,560 & $1,379,109$ \\
\hline
\end{tabular}

Note: (1) Earnings Before Interest, Taxes, Depreciation and Amorization. (2) Earnings Before Interest, Taxes. (3) Earnings Before Taxes. Source: Prepared by the authors. 


\section{MlMacrothink}

Journal of Agricultural Studies

ISSN 2166-0379

2020, Vol. 8, No. 2

The working capital (US\$ 287,400.26) needed to cover deposit expenses until revenue generation began, in addition to the fixed investment (US\$2,675,745.73) were brought into account in the year zero. Working capital in cash flow is the sum of operating costs and warehouse administrative costs. The PFCF, with a positive value of US\$ 442,840.89, remained unchanged over 12 years.

During the grace period, only financial interest of US\$ 113,719.19 per annum should be paid. Payment of financing installments begins in year 13, when PFCF drops to US\$ 275,606.78, although positive. As installments are paid, the PFCF gradually increases until the end of financing in year 20. At the end of the estimated useful life for the storage structure (year 25), the investment returns to PFCF discounting its residual value, $20 \%$ of the invested amount (US\$ 535,149.15) and working capital (US\$ 287,400.26). In year 25, the PFCF has a positive value of US\$1,379,109.49. Studies that analyze the economic and financial viability of implementing storage structures commonly present cash flows in a summarized manner, which makes the analysis and interpretation of results difficult. In contrast, this study stands out for providing more information that is detailed to academic researchers and decision makers.

\subsection{Economic and Financial Viability Indicators}

To evaluate the economic and financial viability of implementing a grain storage structure, the following techniques were used: NPV, IRR, PI, discounted Payback, B/C Ratio, EUAW and MIRR. This more comprehensive set of techniques differs from other viability studies such as Cristiano et al. (2006), Gottardo and Cestari Junior (2008), Pereira and Oliveira (2016), who consider only NPV, IRR and Payback; Vorpagel et al. (2017) and Vergara et al. (2017), who used NPV, IRR, Payback and B/C Ratio; Paz and Aragão (2016), who opted for NPV, IRR, Payback and Sensitivity Analysis techniques.

The results of the application of economic and financial valuation techniques for the investment project evaluated in this study are presented in Table 6.

Table 6. Results of economic and financial viability indicators

\begin{tabular}{l|l}
\hline \multicolumn{1}{c|}{ Indicators } & \multicolumn{1}{c}{ Results } \\
\hline Net Present Value (NPV) & US\$ 922,677.61 \\
\hline Equivalent Uniform Annual Value (EUAW) & US\$ 103,148.32 \\
\hline Internal Rate of Return (IRR) & $14,08 \%$ \\
\hline Modified Internal Rate of Return (MIRR) & $11,39 \%$ \\
\hline Discounted Payback (DP) & 11,81 years \\
\hline Profitability Index (PI) & 1,31 \\
\hline Benefit / Cost Ratio (B/C) & 3,16 \\
\hline
\end{tabular}

Prepared by the authors 
The investment in grain storage structure proposed here presented a positive NPV of US\$ 922,677.61 indicating that the investment is viable. The NPV shows that at the end of the investment, the sum of discounted earnings is greater than the amount invested in the project. This result corroborates the studies by Cristiano et al. (2006), Gottardo and Cestari Junior (2008), Paz and Aragão (2016), Pereira and Oliveira (2016), Vorpagel et al. (2017), Vergara et al. (2017) and Vieira and Dalchiavon (2018). EUAW was US\$103,148.32, which represents the conversion of NPV to annual values and producer's earnings of US\$ 103,148.32 per annum. The project is accepted when EUAW is positive as the viability of the investment is enhanced.

The IRR totaled $14.08 \%$ per annum, demonstrating that the investment returns $10.1913 \%$ per annum above MAR. Therefore, the implementation of the structure is economically attractive, even considering the particularities of an emerging country. Other studies have found attractiveness in storage investment by analyzing IRR, such as Gottardo and Cestari Júnior (2008), Paz and Aragão (2016), Pereira and Oliveira (2016) and Vorpagel et al. (2017). In contrast, Vieira and Dalchiavon (2018) identified an IRR of $6.85 \%$ per annum, lower than the MAR of $10.15 \%$ per annum and Cristiano et al. (2006) identified an IRR of $1.97 \%$ per annum in structures with a capacity of over 100,000 bags. In the latter case, the static capacity and financing conditions were crucial for the viability assessment.

The MIRR was calculated to obtain a more realistic rate for the analysis of reinvestment of interim cash flows. Given the IRR's theoretical assumption that interim cash flows should be reinvested at the end of each year, in this case at a rate of $14.08 \%$ per annum, a reapply rate was proposed as the same charged for the financing to be contracted (FCO - Rural). Thus, an MIRR of $11.39 \%$ per annum was obtained, higher than the MAR, which reiterates the viability of the investment.

Considering the useful life of the investment of 25 years, it was found that the investment is viable in terms of return time, since it presented an updated payback of 11.81 years. Gottardo and Cestari Júnior (2008) found a return time of 5.89 years, Pereira and Oliveira (2016) of 7.3 years and Paz and Aragão (2016) of 5 years. Cristiano et al. (2006) identified viability only with static capacity above 100,000 bags and, in this case, the return on investment occurred in 19 years.

The project's PI was US\$ 1.31, which means that each US\$ 1.00 invested generates US\$ 1.31 of cash flow. The index explains the relationship between investment benefits and initial investment and indicates the value created by each dollar invested. Similarly, the results for the $\mathrm{B} / \mathrm{C}$ Ratio was 3.16. This ratio indicates that the project is attractive because each US\$ 1.00 invested generates a gross amount of US\$ 3.16 and a net amount of US\$ 2.16. Therefore, it confirms the previous results of viability of the investment and reveals a $\mathrm{B} / \mathrm{C}$ ratio higher than that of 1.1586 found by Vorpagel et al. (2017).

The economic and financial indicators derived from capital budgeting techniques used in this study show that investing in storage structures is advantageous. Considering the characteristics analyzed, the investor is adequately remunerated. However, the analysis alone does not provide sufficient information for a valid decision for rural investments in emerging 


\section{Macrothink

countries, where there are uncertainties about the project environment and its investment plan (Balcombe and Smith, 1999). Therefore, this study used the sensitivity analysis in composition with the Monte Carlo method to quantify the inherent risk of the project and to estimate the probability of its success, as detailed in the next sections.

\subsection{Sensitivity Analysis}

To verify the impact that a variation in investment parameters have on NPV, a sensitivity analysis was performed considering the impact of the following variables: Gross Operating Revenue (GOR), Fixed Investment (FI), Operating Cost (OC), Administrative Expense (AE) and Working Capital (WC), as shown in Figure 2.

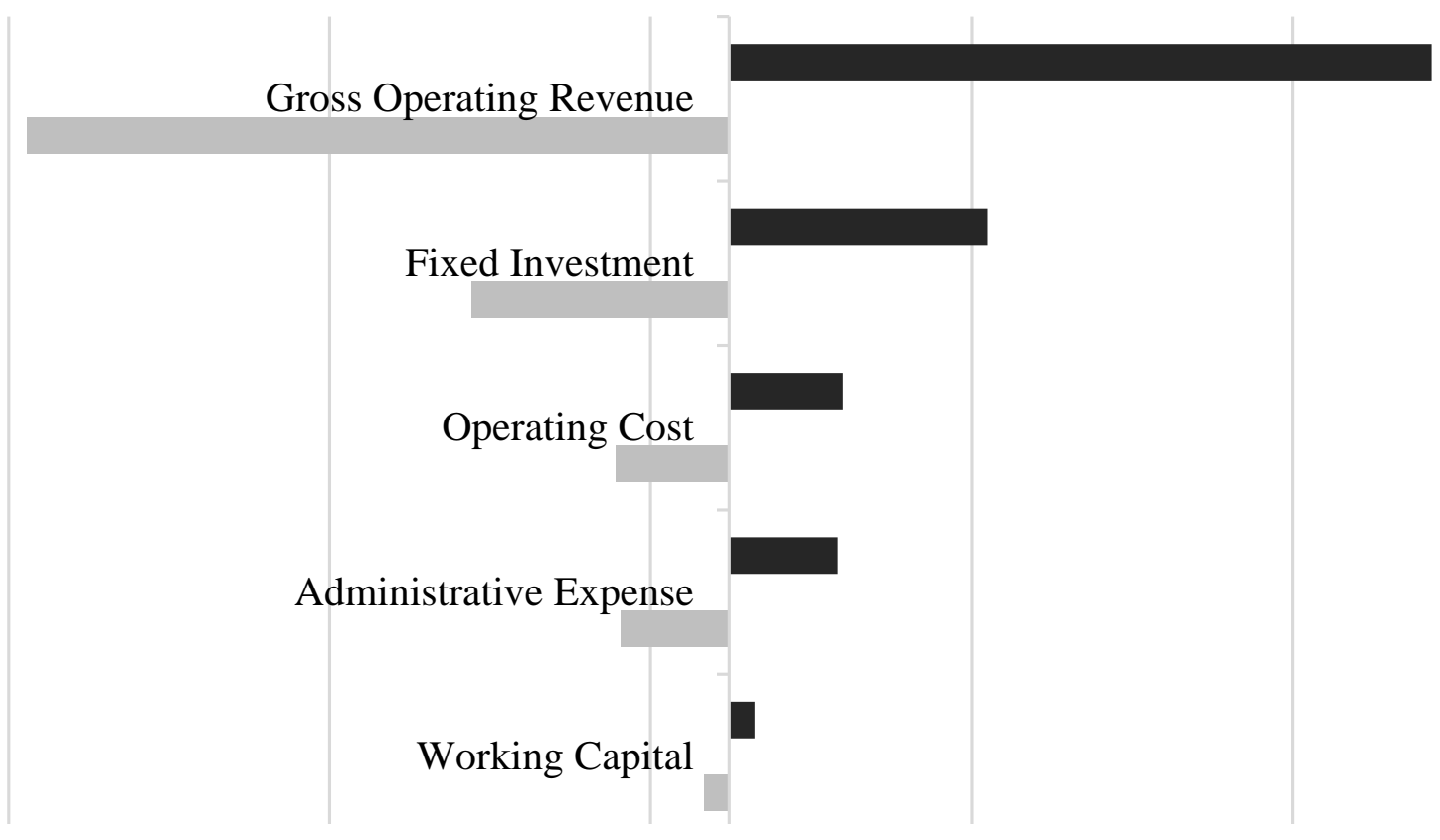

Figure 2. NPV as a function of GOR and FI variations

Source: Prepared by the authors

The results show that NPV is more sensitive to changes in Gross Operating Revenue and Fixed Investment, which are the most relevant parameters for risk analysis. In addition to other contexts, sensitivity analyzes are also successfully applied to verify economic viability (Gransberg and Kelly, 2008; Lukuyu et al., 2019; Talavera et al., 2011). While sensitivity analysis is useful for indicating the most critical parameters of a given investment, risk analysis provides an estimate of project value variability that is more realistic and easier to interpret (Clarke and Low, 1993). This analysis is presented below in section 3.7.

\subsection{Monte Carlo Risk Analysis}

The sensitivity analysis identified that Gross Operating Revenue and Fixed Investment generated greater instability in the results and, therefore, were used in the Monte Carlo simulation. The triangular probability distribution function was adopted in the simulation with a range from $-20 \%$ to $+20 \%$. Results are presented in Table 7 . 


\section{IIMacrothink}

Table 7. Monte Carlo Method Simulation Results

\begin{tabular}{l|c}
\hline NPV Minimum & $-\mathrm{US} \$ 80.345,24$ \\
\hline NPV Maximum & $\mathrm{US} \$ 2.088 .925,42$ \\
\hline NPV Medium & $\mathrm{US} \$ 920.170,05$ \\
\hline Standard Deviation & $\mathrm{US} \$ 269.938,25$ \\
\hline $\mathrm{NPV}>0$ & $99,97 \%$ probability \\
\hline $\mathrm{NPV}<0$ & $0,03 \%$ probability \\
\hline NPV $>$ Average & $49,63 \%$ probability \\
\hline NPV $<$ Average & $50,37 \%$ probability \\
\hline
\end{tabular}

Source: Prepared by the authors.

As with profitability indicators, risk simulations indicate that the project is economically viable, given the high probability of positive NPV (99.97\%) and higher than the calculated average $(49.63 \%)$. Figure 3 shows these probabilities and the frequency of NPVs, estimated at the randomness required by the Monte Carlo Method.

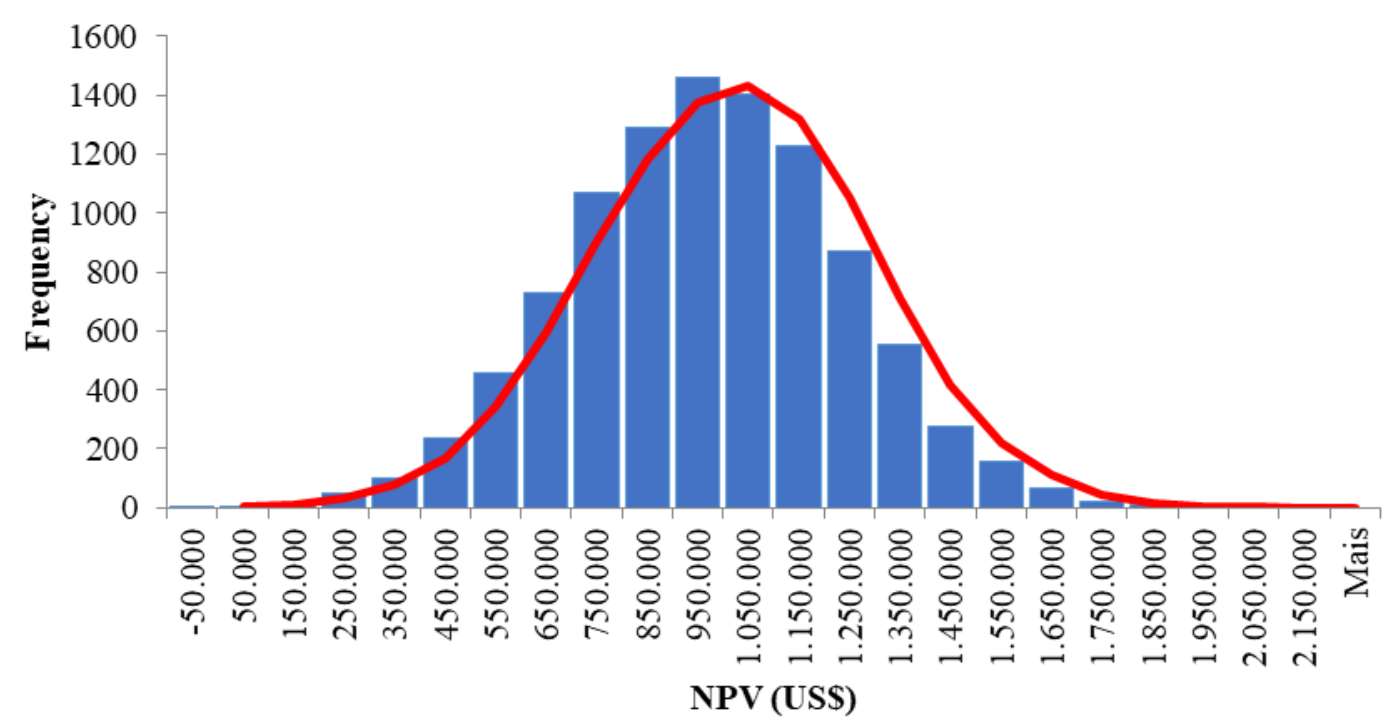

Figure 3. NPV histogram as a function of GOR and FI variations

Source: Prepared by the authors.

The Monte Carlo method allowed 10,000 simulations that considered the impact, in terms of 
risk, of $20 \%$ positive or negative variation in Gross Operating Revenue and Fixed Investment, allowing a broad portfolio of possibilities to support decision making in the event of uncertainty. Changes in Gross Operating Revenue include changes in price and quantity, as well as changes in the price of Fixed Investment components (civil works, machinery and equipment, power grid, road balance), which also fluctuate according to macro and microeconomic variables. Thus, quality and robustness are added to the investment viability analysis performed here.

\section{Summary and Conclusions}

Brazil sets new records of production and export in the grain sector each year, but the grain storage deficit insists on composing the country's logistics scenario. Storage is one of the main items of crop flow logistics, representing financial gains to farmers and increased production capacity of farms. One of the main advantages of storage is the reduction in freight and transportation costs, which are inflated during the crop. High freight and transportation costs are aggravating in the Midwest due to expanding production, lack of farm storage, structural transportation problems and long distance from Brazilian harbors (Fliehr et al., 2019).

Investing in storage increases the grain value, as it ensures the quality obtained in the crop and allows reaching the high standards of the market. In addition, it provides better business management, creating freedom of choice for the decision maker in terms of production flow and marketing. Considering the conditions of the study and based on analyzes of economic and financial viability, sensitivity and risk, it is concluded that investing in grain storage structure at farm level is viable and has the potential to increase agribusiness competitiveness and investor wealth, even in an emerging country.

Economic and financial viability indicators applied from capital budgeting techniques show that storage investment offers favorable conditions for farmers: NPV and EUAW were greater than zero, IRR and MIRR exceeded MAR, the B/C ratio was greater than one, the PI was higher than the initial outlay and the payback was 11.81 years.

In addition, it was found that the investment is $99.97 \%$ likely to have an NPV greater than zero, which is sufficient for producers in this case to decide to implement their own low-risk storage. Therefore, all the process exposed here is valid to support the decision making of producers who wish to implement a storage structure on the farm.

This study contributes to agribusiness management by supporting decision-making on the establishment of grain storage facilities on farms. In addition, it contributes to instruct the entities responsible for promoting agribusiness (government, financial institutions and others) in the analysis and operationalization of credit lines for storage. The study also has academic implications in addressing and broadening discussions on the viability of storage structures from an economic perspective in the context of an emerging country. Discussions in these areas are currently scarce.

The results of this research contribute to the development of Brazilian agribusiness by encouraging investments that contribute to increasing the static storage capacity of grain at 
farm level, prioritizing grain quality and aiming at food security. It also helps policy-makers, because facing a complex phenomenon has the challenge of increasing engagement between government, financing programs and producers, at different levels of production and income, making the dynamics of agricultural production more sustainable and profitable.

\section{References}

Acuña, B. C. M. (2015). Utilidade do valor justo de Ativos Biológicos para a análise de crédito de corporações brasileiras baseadas no agronegócio. Tese - Univ. São Paulo. FEA-USP, São Paulo.

APROSOJA, (2019). Estatísticas da soja [WWW Document]. URL http://www.aprosoja.com.br/comissao/politica-agricola-e-logistica/arquivos (accessed 11.12.18).

Argilés, J. M. (2001). Accounting information and the prediction of farm non-viability. Eur. Account. Rev. 10, 73-105. https://doi.org/10.1080/713764592

Arnold, U., \& Yildiz, Ö. (2015). Economic risk analysis of decentralized renewable energy infrastructures - A Monte Carlo Simulation approach. Renew. Energy, 77, 227-239. https://doi.org/10.1016/j.renene.2014.11.059

Assaf Neto, A. (2005). Finanças corporativas e valor, 2nd ed. Atlas, São Paulo.

Assaf Neto, A., Lima, F. G., \& Araújo, A. M. P. de, (2008). Uma proposta metodológica para o cálculo do custo de capital no Brasil. RAUSP - Rev. Adm., 43, 72-83.

Aubin, J. P., Bayen, A. M., \& Saint-Pierre, P. (2011). Viability Theory, 2nd ed. Springer Berlin Heidelberg, Berlin. https://doi.org/10.1007/978-3-642-16684-6

Balcombe, K. G., \& Smith, L. E. D. (1999). Refining the use of Monte Carlo techniques for risk analysis in project planning. J. Dev. Stud., 36, 113-135.

https://doi.org/10.1080/00220389908422623

Bank of Brazil, (2019). FCO-Rural [WWW Document]. URL https://www.bb.com.br/pbb/pagina-inicial/cooperativas/fco-rural/\#/ (accessed 1.15.19).

Blank, F. F., Samanez, C. P., Baidya, T. K. N., \& Aiube, F. A. L. (2014). CAPM Condicional: Betas Variantes no Tempo no Mercado Brasileiro. Rev. Bras. Finanças, 12, 163-199. https://doi.org/10.12660/rbfin.v12n2.2014.13942

Bocca, L. S., \& Galves, M. L. (2016). Multicriteria Decision aid to Implement an On-Farm Storage System for Soybeans. Eng. Agrícola, 36, 1250-1260. https://doi.org/10.1590/1809-4430-eng.agric.v36n6p1250-1260/2016

Bojanic, A. (2017). Representante da FAO Brasil apresenta cenário da demanda por alimentos [WWW Document]. $\quad$ FAO no $\quad$ Bras. URL www.fao.org/brasil/noticias/detail-events/en/c/901168/ (accessed 5.20.19).

Bordeaux-Rêgo, R., Paulo, G. P., Spritzer, I. M. de P. A., \& Zotes, L. P. (2014). Viabilidade 
econômico-financeira de projetos, 3rd ed. Editora FGV, Rio de Janeiro.

Brealey, R., Myers, S., \& Allen, F. (2013). Princípios de finanças corporativas, 10th ed. AMGH, Porto Alegre.

Casarotto Filho, N., \& Kopittke, B. H. (2010). Analise de investimentos: matemática financeira, engenharia econômica, tomada de decisões, estratégia empresarial, 11th ed. Atlas, São Paulo.

CEPEA, (2019). Índices Exportação do agronegócio 2018 [WWW Document]. URL www.cepea.esalq.usp.br/upload/kceditor/files/Cepea_ExportAgro_2018_.pdf （accessed 5.20.19).

Clarke, R., \& Low, A. (1993). Risk analysis in project planning: a simple spreadsheet application using Monte-Carlo techniques. Proj. Apprais., 8, 141-146. https://doi.org/10.1080/02688867.1993.9726903

CONAB, (2018). Séries históricas [WWW Document]. URL http://www.conab.gov.br (accessed 10.12.18).

Cristiano, A. C., Rodrigues, F. da S., \& Souza, J. P. de, (2006). Viabilidade Econômica do Armazenamento de Soja na Propriedade Rural: vantagem competitiva via Redução de Despesas e Benefícios para a Estratégia de Comercialização. Análise Econômica, 24, 141-160. https://doi.org/10.22456/2176-5456.10853

Damodaran, A. (2010). Avaliação de investimentos: ferramentas e técnicas para a determinação do valor de qualquer ativo, 2nd ed. Qualitymark, Rio de Janeiro.

Damodaran, A. (2019). Betas by Sector (US) [WWW Document]. URL http://pages.stern.nyu.edu/ adamodar/New_Home_Page/datafile/Betas (accessed 2.10.18).

FAO, (2011). Price Volatility in Food and Agricultural Markets: Policy Responses [WWW Document]. G20 Policy Rep. https://doi.org/10.1596/27379

Fliehr, Z. S. (2019). Impacts of Transportation and Logistics on Brazilian Soybean Prices and Exports. Transp. J. 58, 65. https://doi.org/10.5325/transportationj.58.1.0065

Frederico, S. (2011). The Modern Agricultural Frontier and Logistics : the Importance of the Soybean and Grain Storage System in Brazil. Terrae, 8, 26-34.

Garrett, R. D., \&Rausch, L. L. (2016). Green for gold social and ecological tradeoffs influencing the sustainability of the Brazilian soy industry. Journal of Peasant Studies, 43, 461-493. https://doi.org/10.1080/03066150.2015.1010077

Gitman, L. J. (2002). Princípios de Administração Financeira, 7th ed. Harbra, São Paulo.

Gottardo, F. A., \& Cestari Júnior, H. (2008). Viabilidade econômico-financeira de implantação de um sistema de armazenagem de grãos: Um estudo de caso em uma média propriedade rural em Campo Mourão - PR. Rev. em Agronegocio e Meio Ambient., 1, 55-76.

Graham, J. R., \& Harvey, C. R. (2001). The theory and practice of corporate finance: evidence 
from the field. J. financ. econ. 60, 187-243. https://doi.org/10.1016/S0304-405X(01)00044-7

Gransberg, D. D., \& Kelly, E. J. (2008). Quantifying Uncertainty of Construction Material Price Volatility Using Monte Carlo. Cost Eng., 50, 14-18.

IBGE, (2019). Levantamento Sistemático da Produção Agrícola - LSPA [WWW Document]. URL

https://www.ibge.gov.br/estatisticas/economicas/agricultura-e-pecuaria/9201-levantamento-si stematico-da-producao-agricola.html?=\&t=series-historicas (accessed 1.16.19).

IMEA, (2019). Custos de produção [WWW Document]. URL http://www.imea.com.br/imea-site/relatorios-mercado-detalhe?c=4\&s=3 (accessed 1.8.19).

INVESTING, (2018). Índice Bovespa Dados Históricos [WWW Document]. URL https://br.investing.com/indices/bovespa-historical-data (accessed 2.1.18).

JP Morgan, (2018). Embi+ Risco-Brasil [WWW Document]. Ipeadata. URL http://www.ipeadata.gov.br/ExibeSerie.aspx?serid=40940\&module=M (accessed 2.1.18).

King, R. P., Boehlje, M., Cook, M. L., \& Sonka, S.T. (2010). Agribusiness economics and management. Am. J. Agric. Econ., 92, 554-570. https://doi.org/10.1093/ajae/aaq009

Kumar, D., \& Kalita, P. (2017). Reducing Postharvest Losses during Storage of Grain Crops to Strengthen Food Security in Developing Countries. Foods, 6, 8. https://doi.org/10.3390/foods6010008

Longmore, D.R., (1989). The Persistence of the Payback Method: A Time-Adjusted Decision Rule Perspective. Eng. Econ., 34, 185-194. https://doi.org/10.1080/00137918908902987

Lopes, D., Lowery, S., \& Peroba, T. L. C. (2016). Crédito rural no Brasil: desafios e oportunidades para a promoção da agropecuária sustentável. Rev. do BNDES, 155-196.

Lukuyu, J. M., Blanchard, R. E., \& Rowley, P. N. (2019). A risk-adjusted techno-economic analysis for renewable-based milk cooling in remote dairy farming communities in East Africa. Renew. Energy, 130, 700-713. https://doi.org/10.1016/j.renene.2018.06.101

Maia, G. B. da S., Pinto, A. de R., Marques, C. Y. T., Lyra, D. D., \& Roitman, F. B. (2013). Panorama da armazenagem de produtos agrícolas no Brasil. Rev. do BNDES, 40, 161-194.

Maranhão, R. L. A., Júnior, O. A. C., Hermuche, P. M., Gomes, R. A. T., Pimentel, C. M. M., \& Guimarães, R. F. (2019). The spatiotemporal dynamics of soybean and cattle production in Brazil. Sustainability, 11(7), 2150. https://doi.org/10.3390/su11072150

Martinelli, L. A., Naylor, R., Vitousek, P. M., \& Moutinho, P. (2010). Agriculture in Brazil: Impacts, costs, and opportunities for a sustainable future. Curr. Opin. Environ. Sustain., 2, 431-438. https://doi.org/10.1016/j.cosust.2010.09.008

Martínez-Paz, J., Pellicer-Martínez, F., \& Colino, J. (2014). A probabilistic approach for the socioeconomic assessment of urban river rehabilitation projects. Land use policy, 36, 468-477. https://doi.org/10.1016/j.landusepol.2013.09.023 
Oliveira, A. L. R. de, \& Silveira, J. M. F. J. da, (2013). Restructuring of the corn supply chain in Brazil: Facing the challenges in logistics or regulation of biotechnology. Int. Food Agribus. Manag. Rev., 16, 1-24.

Oliveira, O. A. de, Grzebieluckas, C., Nascimento, A. R. da C., \& Maldonado, T. V. (2016). Custos de armazenagem de soja: qual a melhor estratégia, vender na safra ou armazenar? Custose@gronegócio line, 12, 265-281.

Patino, M. T. O., Machado, M. F., Nascimento, G. T. do, \& Alcantara, M. R. de, (2013). Analysis and forecast of the storage needs of soybeans in Brazil. Eng. Agrícola, 33, 834-843. https://doi.org/10.1590/S0100-69162013000400022

Paz, M. V., \& Aragão, T. R. de P. (2016). Viabilidade econômica da construção de uma unidade armazenadora em propriedade rural de Lagoa Vermelha (RS). Rev. iPecege, 2, 66. https://doi.org/10.22167/r.ipecege.2016.1.66

Pereira, L. F. R., \& Oliveira, V. de (2016). Viabilidade ecônomica para a implantação de uma unidade armazenadora de grãos em uma propriedade no municipio de Nova Cantu - PR. Rev. Cultiv. o Saber, 9, 81-91.

Pereiro, L. E. (2001). The valuation of closely-held companies in Latin America. Emerg. Mark. Rev., 2, 330-370. https://doi.org/10.1016/S1566-0141(01)00024-3

Poynder, N. (1999). Grain storage in theory and history, in: Conference of the European Historical Economics Society. EHES, Lisboa, pp. 54-63.

Puzzi, D. (2000). Abastecimento e armazenagem de grãos, 2nd ed. Instituto Campineiro de Ensino Agrícola, Campinas.

Ross, S. A., Westerfield, R. W., \& Jordan, B. D. (1998). Princípios de Administração Financeira, 1st ed. Atlas, São Paulo.

Saath, K. C. de O., \& Fachinello, A. L. (2018). Crescimento da demanda mundial de alimentos e restrições do fator terra no Brasil. Rev. Econ. e Sociol. Rural., 56, 195-212. https://doi.org/10.1590/1234-56781806-94790560201

Silva, L. C. da, Queiroz, D. M. de, \& Flores, R. A. (2006). Estimativa de custos operacionais em unidades armazenadoras de grãos por meio de simulação. Rev. Bras. Armazenamento, 31, $1-7$.

Talavera, D. L., Muñoz-Cerón, E., de la Casa, J., Ortega, M. J., \& Almonacid, G. (2011). Energy and economic analysis for large-scale integration of small photovoltaic systems in buildings: The case of a public location in Southern Spain. Renew. Sustain. Energy Rev., 15, 4310-4319. https://doi.org/10.1016/j.rser.2011.07.119

Teixeira, V. P. M., \& Cunha, M. F. da, (2017). Aplicabilidade dos Modelos CAPM Local, CAPM Local Ajustado e CAPM Ajustado Híbrido ao Mercado Brasileiro, in: XIV Congresso USP de Iniciação Científica Em Contabilidade. FEA-USP, São Paulo, pp. 1-16.

U.S. Department of the Treasury, (2018). Daily Treasury Yield Curve Rates (T-Bond) [WWW 
Document].

Vergara, W. R. H., Oliveira, J. P. C., Barbosa, F. lves, \& Yamanari, J. S. (2017). Análise de viabilidade econômico-financeira para aquisição de uma unidade de armazenagem de soja e milho. GEPROS - Gestão da Produção Operações e Sist., 12, 41-61. https://doi.org/10.15675/gepros.v12i1.1598

Vieira, R. A., \& Dalchiavon, F. C. (2018). Custos e viabilidade da implantação de uma unidade armazenadora de grãos no Mato Grosso. Rev. IPecege, 4, 7-15. https://doi.org/10.22167/r.ipecege.2018.2.7

Vorpagel, F., Costa, N. L., Santana, A. C. de, Mattos, C. A. C. de, \& Oliveira, G. N. de, (2017). Análise de viabilidade econômica da implantação de unidade de armazenamento de grãos com linha de crédito subsidiada pelo Programa para Construção e Ampliação de Armazéns ( PCA ). Custose @gronegócio line, 13, 386-408.

Vose, D. (2002). Risk Analysis: A Quantitative Guide., 2nd ed. John Wiley \& Sons, ltd, London.

Weber, É. A. (2005). Excelência em beneficiamento e armazenagem de grãos. Canoas.

\section{Copyright Disclaimer}

Copyright for this article is retained by the author(s), with first publication rights granted to the journal.

This is an open-access article distributed under the terms and conditions of the Creative Commons Attribution license (http://creativecommons.org/licenses/by/4.0/). 